\title{
English as a foreign language instruction in Ecuador: Implementation of the Content and Language Integrated- Learning during 2019-2021
}

\author{
Pamela Barre-Parrales ${ }^{\text {a, } 1}$, Jhonny Villafuerte-Holguín ${ }^{\text {b,2,* }}$ \\ ${ }^{a}$ Universidad Laica Eloy Alfaro de Manabí, Av. Circunvalación S/N. Manta,Ecuador, 130207, Ecuador \\ b Proyecto Comprensión Lectora y Escritura Académica, y el Proceso de titulación de la carrera PINE de ULEAM, Ecuador \\ ${ }^{1}$ pamela.barre@uleam.edu.ec ; ${ }^{2 * j h o n n y . v i l l a f u e r t e @ u l e a m . e d u . e c ~}$ \\ * corresponding author
}

\section{ARTICLE INFO}

\section{Article history}

Received 25 June 2021

Revised 15 July 2021

Accepted 13 August 2021

\section{Keywords}

English as a foreign language

English language instruction

educational innovation

public policy

reading and writing

\section{ABSTRACT}

Ecuadorian educational policy for English as Foreign Language instruction in Ecuador mandated in 2016 to introduce Content and Language Integrated-Learning (CLIL) methodology to improve the teaching and learning process. This research aims to analyze the implementation of CLIL methodology in zone 4 of Ecuador during 2019-2021. This work subscribed to the transformative paradigm and administrated quantitative and qualitative methods of educational research. The participants were 70 English as a Foreign Language teachers from nine public and private educational institutions located in Manabi Province of Ecuador. The instrument used was the Instructor Perceptions of Differentiated Instruction of Turner, Solis, and Kincade (2017) in an observation format. The information collection techniques used were in-depth interview and focus group discussion. The results allowed the research team to determine the impact of the pandemic on the CLIL implementation in zone 4 of Ecuador. The results show differences in the implementation of the methodology between public and private schools which are linked to internet and technology devices access, teachers' knowledge regarding CLIL methodology, and institutional policies. In regards COVID19 pandemic, it is concluded that it has pacted the implementation of CLIL methodology in both public and private secondary schools that participated in the study.

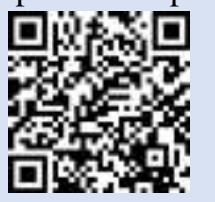

How to Cite: Barre-Parrales, P. \& Villafuerte-Holguín, J. (2021). English as a foreign language instruction in Ecuador: An analysis of the Content and Language Integrated-Learning implementation. English Language Teaching Educational Journal, 4(2), 99-112

\section{Introduction}

Statistics show that Ecuador has fallen in its position of the index of knowledge of English worldwide, going down from position 80 in 2011 to 93 in 2020 (EF, 2020). It is striking because after detecting weaknesses in the English teaching process in 2012, Ecuador implemented some educational policies that are supposed to improve the quality of teaching. Some factors have been assumed to cause the condition, one of them is the issue of learning motivation. At this point, the study of Wang and Littlewood (2021) showed that motivation for learning is a person's motivation to carry out the desired goal, starting from one's motivation to learn to be better than their enthusiasm results of learning activities.

Regarding the learning method, the government policies implemented in Ecuador for teaching English as a Foreign Language included the use of Content and Language Integrated-Learning 
methodology (Ministry of Education of Ecuador, 2016). The Ecuadorian academy expectation was CLIL helps create more meaningful EFL classes to provide more prosperous relations, communication situations, and opportunities that engage learners as stated by Karimi, Lotfi and Biria (2019) and Mayora and Gutiérrez (2019). The said methodology consists of two pedagogical principles: (1) making content understandable by providing comprehensible language input and (2) stimulating productive language for the students to use (Escobar-Urmeneta, 2019).

In relation to the current situation where COVID19 pandemic issue becomes a global issue affecting worldwide, it affects the learning process in Ecuador as well. COVID19 pandemic situation has led to changes in Ecuador national educational system. As a result, the online and hybrid education model emerges, expecting to keep up the younger generations with their learning activities (World Health Organization, 2020). Unfortunately, under Ecuador's socio-economic and technological conditions, access to the internet and technological devices has impacted and distanced the private and public elementary schools.

Encouraged to provide the need to have reliable information regarding the status of the CLIL methodology implementation in Ecuador, the authors of the study proposed the following research questions:

1. How is CLIL methodology implemented in the secondary educational institutions of zone 4 in Ecuador between 2019-2021?

2. How does the COVID19 pandemic impact CLIL implementation process in secondary schools of zone 4 in Ecuador?

This research aims to analyze the implementation of the CLIL methodology in English as a Foreign Language in nine educational institutions located in zone 4 in Ecuador during 2019-2021.

\subsection{Literature Review}

\subsubsection{Content and Language Integrated-Learning (CLIL)}

Marsh et al. (2014) promoted the Content and Language Integrated-Learning (CLIL) method in 1994. CLIL reinforces literature, history, or science lessons with foreign language practices, by promoting 'you can do it!'. It requires teachers to be very well acquainted with the developmental stages of the language learning and the main theories of foreign language acquisition as well. To understand the concept of CLIL better, there are factors that academics need to understand, especially the differences between learning a mother tongue and a foreign language (Marsh et al., 2014). CLIL has four basic principles: (1) content, which successfully places the acquisition of knowledge skills and understanding inherent in that discipline, (2) communication, which defines language as a conduit for communication and learning, (3) cognition, which represents a cognitive challenge for students to improve their thinking and basic interpersonal communication skills and the cognitive-academic language competence, and (4) culture, which functions to encompass to multiculturalism, considering that language, thought, and culture are closely linked (Salamanca \& Montoya, 2017). In addition, in the technological and global society setting nowadays, it is imperative to understand that the knowledge of another language helps learners communicate ideas about science, art, and technology to people worldwide.

Regarding the strengths it holds, CLIL methodology is believed to be able to make meaningful content for meaningful learning and provide more prosperous relations, communication situations, and opportunities that engage learners (Karimi et al., 2019). Besides, Mayora and Gutiérrez (2019) found that, when using CLIL, learners show more favorable attitudes for learning a target language as the central methodology for learning EFL. In addition, Akila and Ilankumaran (2020) argued that CLIL encourages a deeper level of assimilation in students exposed to similar languages and language roles. Karimi et al. (2019) study also showed that English language learners groups find classes more accessible and attractive when it is used the methodology CLIL. However, applying CLIL should be done appropriately as Barrios \& Milla-Lara (2020) and Antropova et al. (2021) who remarked that CLIL incorrect implementation can negatively impact learners' achievement.

\subsubsection{Curriculum and multicultural approach}

Understanding the term curriculum can be different for each person. As a result, practically, how curriculum is applied varies. Some teachers may tend to be concerned with the teaching techniques, while some others are going into more procedural. 
Graves and Garton (2017) argued that the curriculum in foreign language can be classified according to its dominant approache. Approach informs teachers about what to teach and how to teach. In addition, it also impacts the process of formulating teaching goals, selecting contents and their presentation sequences, selecting techniques to use, and designing evaluation procedures. The EFL curriculum also uses diverse kinds of tasks such as collaborative learning and conversational skills to integrate curriculum content with non-native language instruction (Calderon, 2018).

Regarding EFL curriculum development in South American countries, Mayora and Gutiérrez (2019) revealed a persistent difference between the teachers' visions about curriculum. In some schools, the vision of language is less present compared to others. Meanwhile, in some other schools the vision of learning is more dominant. in most schools. However, there are cases in which both the learning vision and the language vision are either absent or posed in vague and unclear ways.

In the case of Ecuador, the Ministry of Education (2016) stated that curriculum is the expression of the educational project that members of a nation prepare to promote the development of the new generations. However, the challenges occur as Ecuador is a multicultural nation. It is the home of 14 nationalities and 18 indigenous communities. The official languages spoken in this country are Castilian, Kichwa, and Shuar. Besides, there are other 14 indigenous languages and 8 different linguistics branches: Barbacoa, Chocó, Jívaro, Quechua, Tukano, Záparo and two language families called Cofan. Thus, such social characteristics demand a multicultural educational system as well.

Practically, according to Intriago et al. (2019), the current Ecuadorian educational system promotes intercultural education, but schools require time and investment to ensure students have access to good linguistic competence. Moreover, technological development through the internet access with high volumes of information and diversity of entertainment activities has been going through academic and social life, which people assimilate as part of the transculturation process. Consequently, this situation requires methodological changes in English language learning process in Ecuador (Ibarra-Rius \& Ballester-Roca, 2017). Fortunately, academics identify CLIL as an appropriate methodology for the Ecuadorian educational context.

\subsubsection{Information and communication technology in the English language instruction}

Educational technology and communication in the EFL context can provide diverse opportunities to innovate the teaching and learning process (Çakici, 2016). ICT emerges to support the links between students and teachers. It helps rebuild the roles and functions of formal education (Casablancas, 2017). Moreover, ICT can promote students' critical thinking and strengthen their problem-solving skills (Pandey et al., 2021). It allows teachers to encourage learners' autonomous and collaborative language practices. Moreover, electronic games and consoles as learning tools can improve the dynamic and enjoyable processes to consider in the curriculum and lesson plans (Wienecke \& Damsgaard, 2020). From students' perspective, according to Cortés-Cabrera and Meléndez-Araya (2021), students positively value the use of ICT and the articulation of the planning of learning objectives. ICT use can enhance students' motivation as well. Hsiao and Su (2021) suggested that as learning motivation, referring to a kind of attitude in which students naturally and willingly participate in learning towards the teaching goal and the internal psychological process set by the teachers, plays a significant role in a learning process, consequently, teachers can use diverse technological devices to increase students' learning motivation, which is a critical condition in every educational context.

Instead of the tremendous benefits it gives, the use of ICT in an educational setting has some drawbacks. Mora (2021) argued that the distance education process cannot replace the teacher's humanity in the classroom during face-to-face classes, so it is worth asking the question. Other limitations of ICT use are related to its accessibility quality and national policies where it applies. In other words, the use of ICT especially in an educational setting needs to be done properly.

\subsubsection{English as a foreign language instruction in Ecuador}

The instruction of English as a Foreign language in Ecuador began in 1950, during the Government of Galo Plaza Lasso. At that period of time, only the students of high school received an hour of English language class per week. English as a Foreign Language (EFL) instruction followed the curriculum reform project aimed at the Development of the Learning of English (CRADLE) for around 30 years. CRADLE program which was created in 1992 with the British Consulate and the Ministry of Education of Ecuador aimed to improve the secondary students' EFL 
acquisition with a local contextualization. It was implemented until 2008, and successfully produced six textbook series called "Our World Through English". The book series were expexted to show the Ecuadorian culture through the topics featuring local themes and characters (Calle et al., 2015).

For decades until the year 2007, EFL used to be an optional school subject in Ecuadorian curriculum. It was taught by teachers paid by the student's families. Later, EFL became part of the secondary school Ecuadorian curriculum with the increase in the instruction duration to two and three hours per week (Cáneppa-Muñoz et al., 2018). In 2010, the Ministry of Education of Ecuador evaluated teachers' English language levels. The results showed that 50\% of teachers reached a basic beginner level base don the European Framework (Calle et al., 2015). Nevertheless, in 2014 the Education First Index reported that Ecuadorian students reached the 65th rank out of 88 countries evaluated worldwide. This unsatisfactory result could be related to a few factors such as the persistence of the overcrowded classrooms in public schools, the little attention given to the process of acquiring the English language, and the lack of specialized teachers for EFL instruction (Intriago et al., 2015).

One of the first changes implemented to improve teaching and learning process in Ecuador was the increment of the number of instructions hours from 3 to 5 hours per week in public educational system (González, 2015). Unfortunately, the EFL class practices commonly consisted of mere grammar and structure explanation and basic vocabulary teaching (Calle et al., 2015). In 2017, the Education Ministry, through the agreement number 0052-14, ordered the incorporation of the English subject into the general primary education curriculum from the second to the seventh grade.

Furthermore, Ecuadorian government set policies implemented to improve the EFL instruction which included: (1) strengthening teachers' communicative competencies until obtaining B2 level of the Common European Framework of Reference for Languages (CEFR), (2) introduction of EFL instruction standards, (3) implementation of program called "Go Teacher" (2014-2018) providing teacher fellows for training abroad, and (4) implementation of the national EFL curriculum in 2017, which recommended the usage of CLIL method as the central methodology to improve students' English language competencies (Ministry of Education, 2016).

In spite of the improvement policies set by the government, the changes in quality didn't appear as expected as the students do not improve their EFL knowledge level (Matamoros et al., 2017). Vélez-Bernal and Ramos-Paredes (2018) added that students only improved their EFL level passing from A1 to A2 when teachers used active strategies whaich reinforced students' knowledge. Furthermore, statistic showed that the overpopulated classes and the focus on the choral repetition of dialogues pre-established by teachers, has distanced learners from the communicative class atmosphere. And it was all related to the Ecuadorian public education policy (Intriago et al., 2019). Consequently, in 2020, the average of the Ecuadorian population EFL knowledge went down negatively to the position of 93rd out of 100 countries (EF, 2020).

Among the previous studies revised appears Wang and Littlewood (2021). They showed that motivation for learning is the strength used to carry out the desired goal, starting from one's motivation to learn to be better than their enthusiasm for learning activities. Regarding the unsatisfactory result, there had been some studies conducted. One of them was the study by Contreras, Picazo, Cordero-Hidalgo and Chaparro-Medina (2021) which recommended that professors should consider students' context and limitations before planning the adjustments to their school programs. They ratified the relevance of teachers' training about educational platforms and technological tools used on education besides government support for issuing laws to formalize virtual education, giving schools the necessary tools and resources to meet their needs. Another study by Antropova et al. (2021) argued that teachers should efficiently use diverse didactic material to implement the CLIL methodology efficiently. Besides, they demonstrated that teachers did not use didactic resources homogeneously, neither did they implement the four principles of CLIL, reducing the efficiency of this method.

\section{Method}

This work subscribes to the transformative paradigm. It administrated the quantitative and qualitative methods of the educational research to collect data and information describing more precisely the changes in the implementation of CLIL in the province of Manabí (Territorial zone 4 
of Ecuador) between 2019-2021. Furthermore, the study has been started within the framework of the consultancy involving 2 expert researchers in the EFL instruction field and the observation of five public and four private schools located in the province of Manabí. In terms of data analysis, the qualitative analysis used follows Avraham (2016) strategies for processing the information using categories helped by the software Atlas Ti $8 \mathrm{v}$. Meanwhile for the statistical analysis to test the research hypothesis, it used SPSS, v25. As for the hypothesis, it's formulated as follows:

$\mathrm{Ho}_{1}$ : There are no significant changes between 2019 and 2021 regarding the implementation of CLIL in the private schools participating in this study.

$\mathrm{Ho}_{2}$ : There are no significant changes between 2019 and 2021 regarding the implementation of CLIL in the public schools participating in this study.

$\mathrm{Ho}_{3}$ : There are no significant differences regarding the implementation of CLIL between Ecuadorian private and public schools between 2019 and 2021.

\subsection{Research Participants}

The research participants presented in Table 1 consisted of seventy EFL teachers from nine educational institutions located in the province of Manabi, Ecuador. The participants reported to be between 28-45 years old with the average teaching experience of eight years.

Table 1. The Sample

\begin{tabular}{|c|c|c|c|c|}
\hline Secondary Schools & Male & Female & Total & Schools \\
\hline \multirow{5}{*}{ Public schools } & 3 & 2 & 5 & 1 \\
\hline & 3 & 1 & 4 & 1 \\
\hline & 2 & 4 & 6 & 1 \\
\hline & 1 & 4 & 5 & 1 \\
\hline & 2 & 13 & 5 & 1 \\
\hline \multirow{4}{*}{ Private schools } & 4 & 1 & 5 & 1 \\
\hline & 5 & 3 & 8 & 1 \\
\hline & 4 & 1 & 5 & 1 \\
\hline & 13 & 4 & 7 & 1 \\
\hline Total & $37(52.8 \%)$ & $33(47.2 \%)$ & $70(100 \%)$ & 9 \\
\hline
\end{tabular}

\subsection{Research Instruments}

The instruments used in this research are the following. Firstly, focus group discussion guide. Focus group discussion guide was used to collect information from EFL teachers concerning the EFL instruction practice under Ecuadorian policy during the COVID19 pandemic. The instrument was designed $a d$ hoc by the research team and validated by a panel of experts belonging to a public university located in Manabí province and having vast experience in the fields of EFL instruction, government policy, and social work. Originally, the focus group discussion guide seven questions. However, the expert panel recommended using only five questions which are related to CLIL implementation.

Secondly, in-depth interview guide. This instrument aimed to collect teachers' opinions about the EFL instruction in Ecuador. The instrument was designed ad hoc, by the research team and validated by a panel of specialists consisting of 3 professionals who belong to a public university located in Manabí province. These specialists have more than 10-year experience in education management, EFL instruction, and government policy. As for the interview guide, it contained seven questions out of twelve as recommended by the panel.

Thirdly, Observation form. - The observation form used was the Instructor Perceptions of Differentiated Instruction of Turner, Solis and Kincade (2017). It was adapted in such a way by the research so that it suited social and educational conditions of Ecuador. The instrument was evaluated and validated by 3 specialists of a public university in Manabí whose expertise are in EFL instruction, education and psychology fields with more than 10-year experience. The 
instrument originally had 28 items, however, the panel recommended only 20 items. Of these 20 items, five items were related to the demographic questions such as: sex, age, length of experience and training in CLIL methodology, and fifteen items were related to CLIL methodology implementation.

\subsection{Research Procedures}

The research conducted through the executed the following stages. Stage 1: Selecting the participants. - The participants were English teachers from different educational institutions located in zone 4 of Ecuador, District Manta-Montecrtisti-Jaramijó. 70 out of the invited 100 teachers agreed to be part of the research. All of these participants signed an informed consent letter following the ethical research regulations of APA. The research project began in June /2019.

Stage 2: Doing the observation process. - The instrument used during this stage was the Instructor Perceptions of Differentiated Instruction of Turner, Solis and Kincade (2017). The research team adapted the instrument to an observation format in 2019. Six groups of students (30 students) from an Ecuadorian public university participated in the data collection process. The observation of the group 1 was carried out between Dec/2019 - Mar/2020 before the COVID19 pandemic. Meanwhile observation of the group 2 was held during the pandemic using Zoom application during Sep-Nov/2020.

Stage 3: Designing guidelines for the focus group discussion and in-depth interview. - The instruments were developed by the research team in March/2020. A panel of specialists reviewed and validated the guidelines.

Stage 4: Conducting focus group discussion. - The activity was carried out in June 2020. Nine teachers participated in it. Following the APA ethics research procedures, the participants signed consent and informed letters. Concerning to the pandemic of COVID19, the focus group discussion was then conducted online using a teleconference application and lasted around an hour.

Stage 5: Doing the interview. - The interview was carried out in September/2020. As the focus group discussion conducter eralier, the interview was done online using Zoom application due to the pandemic. The interview participants signed the informed consent letter following the ethics research procedure of APA. The interview lasted around an hour.

Stage 6: Doing statistical analysis. - The statistical analysis was done using Statistic Package Social Science SPSS, v.24. Considering all the critical points of the CLIL methodology, the present work gathered information contrasting virtual and face-to-face classes. The test applied was the Wilcoxon test for related series with the p-value 0.050;

Stage 7: Doing categorial analysis. - The categories used in this analysis were: (1) Teacher training for ELF instruction. Subcategories 1 comprised: (1.1.) Teachers' knowledge, (1.2.) Teachers' challenges for CLIL implementation, (2) Challenges for teaching during the pandemic. Meanwhile subcategories 2 consisted of: (2.1.) Implementation advances, (2.2.) CLIL implementation limitations, and (3) Materials and resources used for EFL teaching during the pandemic time. And subcategories 3 included (3.1.) Materials availability and (3.2.) Resource availability.

\section{Findings and Discussion}

\subsection{Research Findings}

The results presentation follows the order of the research questions formulated in the previous Introduction section.

\subsubsection{Implementation of CLIL during 2019-2021 period in secondary schools of Manabi, Ecuador}

Table 2 presents the analysis of teachers' voices collected during focus group discussion. The FGD was conducted to collect information about participants' CLIL knowledge and training and their challenges for implementing the methodology in 2019-2020 period during the COVID19 pandemic. 
Table 2. Teachers' Challenges for the Implementation of EFL Instruction Policy in Ecuador

\begin{tabular}{|c|c|c|}
\hline Category 1: Teacher training & $\begin{array}{l}\text { Teachers' } \\
\text { knowledge }\end{array}$ & $\begin{array}{c}\text { Teachers' } \\
\text { Challenges for } \\
\text { implementation }\end{array}$ \\
\hline $\begin{array}{l}\text { E1.10 "We have not had strong training for EFL online instruction. It was } \\
\text { not part of the curriculum; it was not taught." } \\
\text { E4.17 "Training processes have been so short that it has not had that } \\
\text { follow-up cycle, where it was found that what was acquired is really being } \\
\text { carried out in the classroom, that is why teachers fight and continue to ask } \\
\text { for training." } \\
\text { E7.22 "Teachers with a lot of experience as teachers pay little attention to } \\
\text { short trainings from the Ministry of Education. Online instruction is } \\
\text { something new for us" }\end{array}$ & $\begin{array}{l}\text { Teachers without } \\
\text { experience about } \\
\text { online education }\end{array}$ & $\begin{array}{l}\text { No available } \\
\text { resources. } \\
\text { No follow-up on } \\
\text { CLIL use. } \\
\text { Teachers feel stress } \\
\text { because the online } \\
\text { education. }\end{array}$ \\
\hline Category 2: Challenges for teaching during the pandemic & $\begin{array}{c}\text { Implementation } \\
\text { Advances }\end{array}$ & $\begin{array}{c}\text { Implementation } \\
\text { Limitations }\end{array}$ \\
\hline $\begin{array}{l}\text { E1.02. "We the teachers do not have the time for do too many activities } \\
\text { students need to learn in a meaningful way. For me, the most complicate is to } \\
\text { teach to students with disabilities." } \\
\text { E4.04. "Many of the activities are not carried out due to the lack of materials } \\
\text { in students' houses. Parents try to support their kids to carry out learning } \\
\text { activities that for many of them do not make sense". } \\
\text { E6.12 "The limitation we have are too many. We should take decisions about } \\
\text { what is the most relevant of the curriculum to teach. } \\
\text { The most complicated for me is to apply evaluations. I have not permanent }\end{array}$ & $\begin{array}{l}\text { Limited class time. } \\
\text { Students are kept in } \\
\text { learning activities. } \\
\text { Teaching basic } \\
\text { grammar } \\
\text { prioritized. }\end{array}$ & $\begin{array}{l}\text { Connectivity } \\
\text { limitations. } \\
\text { Students support } \\
\text { the students } \\
\text { learning. } \\
\text { Limitation of } \\
\text { access to devices }\end{array}$ \\
\hline
\end{tabular}
access to Internet.

\section{Category 3: Materials and resources for EFL teaching during the pandemic.}

E6.14 "The study guides are very heavy and long so that many students cannot see them on mobile electronic devices."

E7.12 "To work on online education during this pandemic year 1, I have had to limit my classes to the fundamentals of teaching grammar. I feel unmotivated as a teacher".

E9. 14 "It's a shame, but I feel like I have regressed in class. We no longer have time to practice reading and listening comprehension, etc. Students take little interest in learning EFL."

\section{Materials' availability \\ Resource's availability}

Poor quality internet. Content's priorities.

Limited time to teach online.
The motivation to learn EFL has decreased.

Less interest in learning EFL

b. Source: Focus group. Jun/2020.

Category 1: Teacher training. The evidence showed that teachers had limitations in the training process, which made it challenging to develop and transmit information that would facilitate joint learning and teachers' training about online education. Those factors have affected the efficiency of the EFL teaching process and their career development.

Category 2: Challenges for teaching during COVID19 pandemic. The evidence showed that teachers should encourage the learners' skills development while maintaining continuous attention. The implementation of CLIL had crucial limitations especially on the search for proactive teaching strategies and this resulted in students' less language production.

Category 3: The materials and resources for EFL instruction during COVID19 pandemic. The data showed that teachers did not have adequate didactic materials and resources for them to switch to an online learning mode. As a result, the students had lost interest in learning English. In such scenarios, CLIL methodology provided support for teachers to be trained in how to use the intended methodology, especially for social studies and science subjects.

Table 3 presents an analysis of the causes due to the decline in the use of CLIL methodology in EFL classes during the pandemic. The categories used in this comparation were: (1) Teachers training in CLIL methodology, (2) Access to technology, and (3) Attention given to EFL subject. 
Table 3. Comparative Analysis of EFL Instruction between Public and Private Schools 2019-2021

\begin{tabular}{l} 
Public schools \\
\hline (1) Teachers' training about online teaching \\
The teachers have not been trained in CLIL. \\
Teachers do not differentiate between Soft CLIL and Hard \\
CLIL activities. \\
The texts are designed with the face-to-face methodology, but \\
the teachers do not know it. \\
Most of the schools apply Soft CLIL (little articulation of the \\
contents of Natural Sciences and History).
\end{tabular}

Private schools

\section{(2) Techers' access to ICT for teaching during COVID19 pandemic}

They have no online platforms to practice English classes using CLIL.

The work guides are applied where all the weekly activities appear. A small part corresponds to EFL.

Internet access limitations reduce the chances of advancing with classes with the CLIL method.
Teachers have been trained in the use of CLIL since 2017.

Teachers differentiate between Soft CLIL and Hard CLIL activities.

The texts are designed with the CLIL method.

Teachers use Hard CLIL in subjects as Natural environment and Sciences, History and Geography.

\section{(3) Attention given to EFL subject \\ Insufficient time for online English classes to apply CLIL. Parents do not attach importance to learning English. Institutional policies prioritize the permanence of students in learning activity despite ICT access limitations. Mathematics and Spanish language are prioritized as preparation for PISA. \\ Enough time of the online English classes to apply CLIL. \\ Parents place high importance on learning English. Institutional policies prioritize the permanence of students in learning activity despite ICT limitations. Mathematics and Spanish language are prioritized for the PISA exams.}

They have online platforms to use CLIL in English classes.

Students having good connections can complete their schedule in online classes.

Teachers give priority to the class contains to warranty students advance in their learning.

c. Source: In-depth interview to EFL teachers from zone 4 of Ecuador. Jun/2020.

Category 1: Teacher training in online education. The evidence showed that private school teachers differentiated and created activities depending on whether the methodology was categorized into soft or hard CLIL; meanwhile, teachers in public schools did not differentiate between these two kinds of CLIL. As a consequence, teachers' productivity became lower and it limited student's achievement.

Category 2: Access to ICT during COVID19 pandemic. The evidence showed that teachers of public schools informed that they had limitations to access technology. They had no specific platform for teaching and learning, and the students did not have mobile devices to join the online synchronous classes. In contrast, teachers of private schools showed good experience in using ICT since they used to work with virtual platforms even before the pandemic occured. Besides, parents from private schools gave high priority to online EFL learning.

Category 3: Attention given to EFL subject. The evidence showed that in public schools the technical limitations and institutional policies did not give much attention to the English subject during the pandemic which eventually affected students' EFL learning significantly. Moreover, teachers had to direct their explanations to grammar topics only. As a result, they did not have time to do engaging learning activities like gamification or other engaging learning activities. On the contrary, the activities in the private schools were planned well and teachers had ample time to conduct each planned activity from introduction to evaluation.

Figure 1 shows the comparison of CLIL methodology implementation between 2019 (before the pandemic) and 2021 (during the pandemic). The private schools reduced their rate of CLIL methodology implementation from 30\% - 45\% in advance in 2019 to $46 \%$ in advance in 2021 . The implementation continued. Meanwhile, CLIL implementation in public schools reduced from 15\% in advance in 2019 to $13 \%$ in 2021. The students had online synchronous classes with their teachers once a week sharing 90 minute session as the other subjects. 


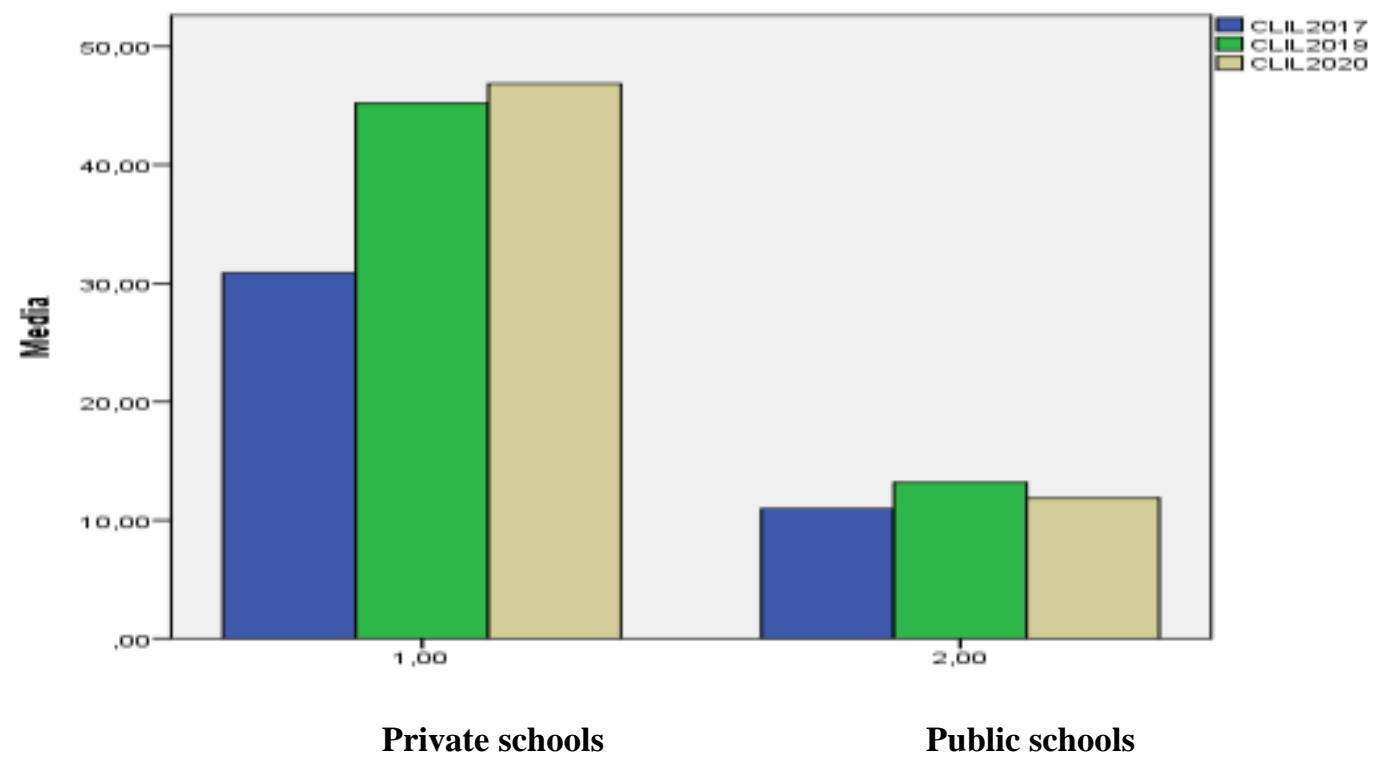

Fig. 1. : The contrast CLIL implementation in public and private schools of zone 4 of Ecuador during 2019-2021.

Source: Survey. Project registers (July. /2021)

The normality test of the Kolmogorov-Smirnov data series did not pass, as presented in Table 4. Therefore, nonparametric hypothesis tests should be conducted.

Table 4. Normality Tests of Data Series

\begin{tabular}{|c|c|c|c|c|c|c|}
\hline & \multicolumn{3}{|c|}{ Kolmogorov-Smirnov ${ }^{a}$} & \multicolumn{3}{|c|}{ Shapiro-Wilk } \\
\hline & Statistic & gl & Sig. & Statistic & gl & Sig. \\
\hline CLIL_PRIVATE_2019 & .148 & 25 & 166 & .906 & 25 & .024 \\
\hline CLIL_PRIVATE_2020 & .247 & 25 & .000 & .866 & 25 & .004 \\
\hline CLIL_PUBLIC_2019 & 400 & 25 & .000 & 642 & 25 & .000 \\
\hline CLIL_PUBLIC_2020 & .368 & 25 & .000 & .745 & 25 & .000 \\
\hline
\end{tabular}

Ho$_{1}$ : There are no significant changes between 2019 and 2021 regarding the implementation of CLIL in the private schools participating in the research.

To answer the $\mathrm{Ho}_{1}$, the Wilcoxon test for related series was administered with the $p$-value 0.050; and the result was 0.000 . Therefore, in Table 5, it shows that the null hypothesis is rejected. It means that there are significant differences regarding the implementation of CLIL during 20192021 in the private schools participating in the study.

Table 5. Hypothesis Test Report Ho1

\begin{tabular}{lllll}
\hline \multicolumn{1}{c}{ Hipótesis nula } & \multicolumn{1}{c}{ Test } & Sig. & \multicolumn{1}{c}{ Decisión } \\
\hline 1 & La mediana de las diferencias entre & $\begin{array}{l}\text { Prueba de Wilcoxon } \\
\text { de los rangos con } \\
\text { CLIL_PRIVATE_2019 y }\end{array}$ & & Rechazar la hipótesis \\
CLIL_PRIVATE_2020 es igual a 0 & signo de mestras \\
& relacionadas & .000 & nula. \\
\hline
\end{tabular}

Asymptotic significances are shown. The significance level is .050.

$\mathrm{Ho}_{2}$ : There are no significant changes between 2019 and 2021 regarding the implementation of CLIL in the public schools participating in the research.

In Table 6, to answer the $\mathrm{Ho}_{2}$, the Wilcoxon test was administered for related series with the $p$ value 0.050 ; the result is 0.000 . Therefore, the null hypothesis is rejected. It means that there are 
significant differences regarding the implementation of CLIL during 2019-2021 in public schools that participated in the study.

Table 6. Hypothesis Test Report for Ho2

\begin{tabular}{llll}
\hline \multicolumn{1}{c}{ Hipótesis nula } & \multicolumn{1}{c}{ Test } & Sig. & Decisión \\
\hline 1 & La mediana de las diferencias entre & $\begin{array}{l}\text { Prueba de Wilcoxon } \\
\text { de los rangos con } \\
\text { CLIL_PRIVATE_2019 y }\end{array}$ & $\begin{array}{l}\text { signo de mestras } \\
\text { relacionadas }\end{array}$ \\
CLIL_PRIVATE_2020 es igual a 0 & .000 & $\begin{array}{l}\text { Rechazar la hipótesis } \\
\text { nula. }\end{array}$ \\
\hline
\end{tabular}

Asymptotic significances are shown. The significance level is .050.

\section{Ho3: There are no significant differences regarding the use of CLIL between private and public schools in the periods 2019-2021.}

To answer the $\mathrm{Ho}_{3}$, the independent sample median test was administered with the $p$-value 0.050 ; and the result was 0.000 . Therefore, Table 7 shows that the null hypothesis is rejected. It means that there are significant differences regarding CLIL implementation during 2019 and 2021 period between public and private schools that participated in the study.

Table 7. Hypothesis Test Report for Ho3

\begin{tabular}{|c|c|c|c|c|}
\hline & Hipótesis nula & Test & Sig. & Decisión \\
\hline 1 & $\begin{array}{l}\text { La distribución de CLIL2020 es la misma } \\
\text { entre las categorías de GRUPO }\end{array}$ & $\begin{array}{l}\text { Prueba de Mann- } \\
\text { Whitney de muestras } \\
\text { independientes }\end{array}$ & .000 & $\begin{array}{l}\text { Rechazar la hipótesis } \\
\text { nula. }\end{array}$ \\
\hline
\end{tabular}

Asymptotic significances are shown. The significance level is .050.

\subsection{Discussion}

Based on the reviewed literature and the research results obtained, the authors argue that teachers of zone 4 of Ecuador tend to consider implementing the methodology CLIL as a government decision imposed in the national EFL curriculum. Therefore, it is evident that EFL teachers look at the curriculum as a learning approach to fulfill, instead of a tool in a permanent construction for improving the teaching and learning process. It is a situation that ratifies the Mayora and Gutiérrez (2019) position when teachers assume the curriculum only from the learning approach point of view.

The information collected allows to help determining that there are differences in the EFL teaching motivation between public and private school teachers. The results obtained ratify what Wang and Littlewood (2021) stated regarding motivation. As motivation is considered the strength capable of moving people to work harder and harder to reach the desired goal, teachers of public and private schools in Ecuador have experienced different ways of managing their teaching motivation. Moreover, the current COVID19 condition has been putting the educational systems as well as teachers under high stress, which decreases their motivation in teaching.

As for the results of the participants' voices, after analyzing them, the authors disagree with the Ministry of Education (2016) point of view regarding the pertinence of CLIL methodology for the EFL online clases, especially when there's a vast contrast between instruction expectations and the social, economic, and technological conditions of the families living in zone 4 of Ecuador. This point of view is also argued by Contreras, Picazo, Cordero-Hidalgo and Chaparro-Medina (2021). They recommend considering students' context and limitations when planning certain school programs, including CLIL methodology. Besides, there are no previous records in Ecuador to affirm that CLIL can produce positive results in students' English language acquisition. It is like an unknown methodology for most of the EFL teachers taking part in the research. As a result, especially among public school teachers, they tend to not put CLIL methodology into practice because they do not have enough knowledge about it. One of the solutions to such a circumstance is by giving teachers training on both methodology and technology. For this, the authors ratify 
Contreras et al. (2021) regarding teachers' training on platforms and technological tools used for linguistic purposes. They recommend that the universities that train English teachers in Ecuador should consider including CLIL methodology as one of the topics in their curriculum of EFL teacher training program.

Another issue regarding CLIL implemetation is related to the intented subjects to teach. In practice, the students of public schools should attend online classes once a week for 90 minutes long by continuously listening to their teachers' explanations of such subjects as Mathematics, Literature, Social Studies, and English language. The main instruction for English teachers is to teach the target language and use it as the teaching approach for essential communication in everyday life. However, such a strategy is not clear for most of the teachers. Using English separately among subjects is note ay to do because they consider everyday life involves comprehensive subjects including health and care topics, social life, family interaction, pets care, house organization, intergeneration communication, and sports practice.

In regards with learning media, in harmony with Karimi et al. (2019), the authors argue that the use of recycled objects as educational materials can effectively allow students to strengthen their learning environment and nature conservation attitudes. Meanwhile, regarding the use of graphic organizers, Pazan-Torres et al. (2017) and Antropova (2021) state that it provides learners with more possibilities to remember more information during online EFL classes.

As for the problems arising during the learning process, both public and private school teachers have experienced them though differently. Private school teachers participating in the research state that they have shortcomingsin regarding issue of the EFL standards and the way of handling the curriculum in a practical level. One of the causes of this is because they commonly use imported books with less local contextualization. Meanwhile, base don the results, public school teachers face more complex problems. It is evident that because public schools have limitations of internet connectivity, teacher training on CLIL, and limited access to didactic materials as well, it has caused teachers feel difficult in implementing CLIL methodology in their clases.

In sum, the observation of EFL classes in nine educational institutions taking part in the research allows affirming that CLIL methodology implementation in Ecuador has been reduced. Besides, the collected data also allows inferring that the way how the Ecuadorian government educational policy has been implemented or practised differently by teachers of public and privates schools.

In terms of what way to improve the EFL quality and thus to move the Ecuadorian English knowledge index towards better place in English global index, it is probably necessary to improve teachers' training programs. When teachers are better trained, the students will have better English proficiency and viceversa. And when the students have low EFL proficiency, it will make them hard to access international scholarships to continue their studies abroad.

\section{Conclusion}

The research concluded remarkable differences in the CLIL methodology implementation process between public and private schools in zone 4 of Ecuador during 2019-2021. Regarding COVID19 pandemic, the results confirm that pandemic had impacted negatively on the implementation of CLIL during 2020-2021. Results show private schools passed from CLIL implementation progress speed of 45\% in 2019 (before COVID19) to 46\% implementation. Having only $1 \%$ of improvement. However, public schools passed from 15\% CLIL implementation progress in 2019 to $13 \%(-2 \%)$ in 2020 . This phenomenon is probably related to the lack of internet connectivity, especially in rural schools, and institutional policies that gives more priorities to subjects such as as mathematics and national language.

Hopefully, the study enriches the information regarding CLIL implementation and can be useful for institutions which are in charge of evaluating government policy implementation. Besides, schools can use the information to make decisions concerning EFL instruction. The weakness of thisstudy, however, could be related to the size of its corpus (seventy EFL teachers from nine secondary schools), which does not allow to generalize the results to all EFL teachers of this geographical zone. Finally, the authors invite other researchers to direct new studies to generate new information about the state of CLIL methodology in Ecuador and other Latin American countries. 


\section{Acknowledgment:}

The authors would like to thank Universidad Laica Eloy Alfaro de Manabí for the support on this research process.

\section{Declarations:}

This work subscribes to the research projects of the Faculty of Education Science of the Universidad Laica Eloy Alfaro in Manabí, Ecuador. (1) Project 'Comprensión lectora y escritura académica - LEA: cambiando vidas desde la educación para la paz, 2021' and (2) Project 'Innovación y Desarrollo de procesos educativos 2018-2021'.

Author contribution : PBP: initiated the research ideas, instrument construction, data collection, analysis, and draft writing; JVH revised the research ideas, literature review, data presentation and statistics analysis, and the final draft.

Funding statement : Non apply.

Conflict of interest : The authors declare no conflict of interest.

Additional information: No additional information is available for this paper.

\section{REFERENCES}

Akila, S. \& Ilankumaran, M. (2020). Developing speaking skill through content language and integrated learning. Tamilnadu, India. Journal of Xi'an University of Architecture \& Technology, 12(8), 857-868

Antropova, Garcia-Noblejas \& Carrasco (2021). Teachers' efficiency of CLIL implementation to reach bilingualism in primary education. Journal of Learning Styles 14 (27), 6-19

Avraham, E. (2020). Destination marketing and image repair during tourism crises: The case of Egypt. Journal of Hospitality and Tourism Management, 28 (4), 41-48.

Barrios, E. \& Milla-Lara, M.D. (2020). CLIL methodology, materials and resources, and assessment in a monolingual context: an analysis of stakeholders' perception in Andalusia. The Language Learning Journal, 48 (1), 60-80. https://doi.org/10.1080/09571736.2018.1544269

Çakici, D. (2016). The use of ICT in teaching English as a foreign language. Participatory Educational Research (PER) Special Issue, IV, 73-77.

Calderon, L. (2019). Content and Language Integrated Learning (CLIL) en la producción oral del idioma inglés. Quito, Ecuador: Universidad Central del Ecuador.

Calle, A. M., Argudo, J., Cabrera, P., Calle, M. D. \& León, M. V. (2015). El impacto de la capacitación a profesores fiscales de inglés de Cuenca. Maskana, 3(1), 53-68.

Cáneppa Muñoz, C., Dahik Solís, C. \& Feijóo Rojas, K. (2018). The history of English language teaching in Ecuador. Revista Pertinencia Académica, 7(1), 39-52.

Casablancas, S. (2017). It is not bad to lose the way: Recofigurations of the teaching role in the digital. En Autores varios. Educar en la era digital (pp. 17-33). Editorial Pandora, S.A.

Contreras, C.P., Picazo, D., Cordero-Hidalgo, A. \& Chaparro-Medina, M. (2021). Challenges of virtual education during the covid-19 pandemic: Experiences of Mexican University professors and students. International Journal of Learning. Teaching and Educational Research, 20(3), 188-204. https://doi.org/10.26803/ijlter.20.3.12.

Cortés-Cabrera, M. A. \& Meléndez-Araya, N. (2021). Pedagogy, technology, creativity, and the use of learning objects in higher education. Revista Peruana de Educación, 3(6), 72 - 81.

Education First EPI, (EF). (2020). El ranking mundial más grande según su dominio del inglés. In: https://www.ef.com.ec/epi/ (accessed 10 January 2021)

Escobar-Urmeneta, C. (2019). An Introduction to Content and Language Integrated Learning (CLIL) for teachers and teacher educators. CLIL Journal of Innovation and Research in Plurilingual and Pluricultural Education, 2(1), 7-19. Doi:10.5565/rev/CLIL.21. 
Graves, K. \& Garton, S. (2017). An analysis of three curriculum approaches to teaching English in publicsector schools. Language Teaching, 50(4), 441-482. Doi: 10.1017/S0261444817000155.

González, M. (2015). La enseñanza-aprendizaje del idioma inglés: métodos y estrategias. Monográfico Santiago, 1(1), 145-163.

Hsiao, P. \& Su, C. (2021). A Study on the Impact of STEAM Education for Sustainable Development Courses and Its Effects on Student Motivation and Learning. Sustainability, 13, 3772. https:// doi.org/10.3390/su13073772

Intriago, E., Morales, M.A. \& Soto, K. (2015). English language teaching in Ecuador: An analysis of its evolution within the national curriculum of public primary schools. Ecuador: Editorial UTMachala.

Intriago, E., Villafuerte, J., Bello, J. \& Cevallos, D. (2019). Teaching and learning English at the university: challenges from the ecuadorian context. In A. Bon, M. Pini, \& H. Akkermansculture. Citizenship, Participation - Comparative Perspectives from Latin America on Inclusive Education. Pangea.

Ibarra-Rius, N., Ballester-Roca, J. \& Marín, F. (2018). Encrucijadas de la competencia mediática y la ciudadanía: uso y consumo de aplicaciones educativas. Prisma Social Revista de Investigación Social, 20(1), 93-113.

Karimi, P., Lotfi, A. R. \& Biria, R. (2019). Enhancing pilot's aviation English learning, attitude and motivation through the application of Content and Language Integrated Learning. International Journal of Instruction, 12(1), 751-766.

Marsh, D., Mehisto, P., Wolff, D., \& Frigols, M. (2014). European framework for CLIL teacher education. European centre for modern language. In: https://www.unifg.it/sites/default/files/allegatiparagrafo/2001-2014/european_framework_for_clil_teacher_education.pdf (accessed 20 march 2021).

Matamoros, J.A., Rojas, M.A., Pizarro, J., Vera, S. \& Soto, S.T. (2017). English language teaching approaches: A comparison of the grammar-translation, audiolingual, communicative, and natural approaches. Theory and Practice in Language Study, 7(11), 965-973.

Wang, S., \& Littlewood, W. (2021). Exploring students' demotivation and remotivation in learning English. System, 102617. In Press. https://doi.org/10.1016/j.system.2021.102617

Mayora, C. \& Gutiérrez, D. (2019). Análisis del currículo del área de inglés en escuelas oficiales de Cali. Lenguaje, 47(2), 685-707. doi: 10.25100/lenguaje.v47i3.7519

Ministry of Educación. (2016). Currículo de los niveles de educación obligatoria. Ecuador. (accessed 4 January 2021).

Mora, F. (2021). Nada puede sustituir la humanidad del maestro en el aula. Educacion 3.0. https://www.educaciontrespuntocero.com/entrevistas/francisco-mora-humanidad-maestro/ (accessed 25 January 2021).

Pandey, D., Ogunmola, G.A., Enbeyle, W., Abdullahi, M., Kumar, B. \& Pramanik, S. (2021). Covid-19. A framework for effective delivering of online classes during lockdown. Journal Arenas (1), 1-10. https://doi.org/10.1007/s42087-020-00175-x.

Pazan-Torres, J.C., Pullas-Tapia, S., Nuñez-Hernandez, C.E. \& Amora-Sanchez, R. (2017). Estilo de aprendizaje visual: Una estrategia educativa para el desarrollo de la memoria a largo plazo. Revista de Estilos de Aprendizaje, 10(20), 240-261.

Salamanca, C. \& Montoya, S. I. (2017). Uso del enfoque CLIL como estrategia de internacionalización del currículo en una institución de educación superior colombiana. Colombia: Universidad de San Gil. (Accessed 22 March 2021).

Turner, W., Solis, O. \& Kincade, D. (2017). Differentiating instruction for large classes in higher education. International Journal of Teaching and Learning in Higher Education, 29(3), 490-500.

Vélez-Bernal, D. \& Ramos-Paredes, I. (2018). Estrategias activas para la enseñanza del idioma inglés como lengua extranjera a los estudiantes de la universidad central del Ecuador. Revista publicando, 5(1), 490506.

Wienecke, J. \& Damsgaard, L. (2020). Boldspilsundervisning i Teori og Praksis. 1st edn. København: Forlaget Hetland. 
World Health Organization, WHO. (2020). WHO Director-General's opening remarks at the media briefing on COVID-19 - 1 April 2020 (p. 1). https://www.who.int/dg/speeches/detail/who-directorgeneral-sopening-remarks-at-the-media-briefing-on-covid-19---1-april-2020 (accessed 6 January 2021). 